\title{
Analysis of Regional Financial Capabilities In Supporting the Implementation of Regional Autonomy in Toraja Utara District In $2014-2019$
}

\author{
Mariana Limbong \\ Magister of Local Government Finance, \\ Faculty of Economics and Business, Hasanuddin University \\ Indonesia.
}

\author{
Haliah \\ Faculty of Economics and Business, Hasanuddin University \\ Indonesia.
}

\begin{abstract}
This study aims to examine and analyze the level of regional financial capability in supporting the implementation of regional autonomy in the North Toraja Regency in 2014 - 2019. The research method used in this research is quantitative descriptive. This study seeks to calculate, describe and analyze the financial component data of the North Toraja Regency Government. The data analyzed in this study are data sourced from the North Toraja Regency budget realization report in 2014-2019, the North Toraja Regency Locally-generated report in 2014-2019 and the 2014-2019 North Toraja financial report. The results of this study conclude that financial capability does not yet support the implementation of regional autonomy in North Toraja Regency in 2014-2019. This is caused by, among others: (1) The ratio of the degree of fiscal decentralization is very less; (2) the financial dependency ratio is very high; (3) The financial independence ratio is very low and has an instructive relationship pattern; (4) The effectiveness ratio of LGR is less effective; (5) LGR efficiency ratio is less efficient; (6) the ratio of routine ability indexes is very less; (7) Locally-generated revenue (LGR) growth ratio is very volatile.
\end{abstract}

Keywords:- regional autonomy, locally-generated revenue , regional financial ability,

\section{INTRODUCTION}

The implementation of Law Number 32 of 2004 concerning Regional Government and Law Number 35 of 2004 concerning Financial Balance between Central and Regional Governments will be able to provide broad, real and accountable authority or autonomy to regional governments proportionally. This is realized by regulating, sharing and utilizing national resources, as well as democratic central and regional financial balances, community participation, equity and justice, and paying attention to the potential and diversity of the region, especially to district and city governments. The purpose of
Nur Dwiana Sari Saudi

Faculty of Economics and Business, Hasanuddin University Indonesia

granting authority in the implementation of regional autonomy is to improve people's welfare, equity and social justice, democracy and respect for local culture, and pay attention to the potential and diversity of the region (Tangkilisan, 2005)

The financial aspect is one of the basic criteria to be able to know clearly the ability of the region to manage its own households (Kaho, 1998). The capacity of the region in question is to what extent and how far the regions can explore their own financial resources to finance regional needs without having to always rely on aid and subsidies from the central government. In addition, one of the important criteria for knowing the region's real ability to regulate and manage its households is the ability of selfsupporting in the financial sector. This opinion shows that finance is an important factor in measuring the level of regional capability in carrying out its autonomy.

Regional financial capacity can be seen from the size of the Locally-generated revenue (LGR) obtained by the region concerned. In relation to granting greater regional autonomy to the regions, LGR is always seen as one indicator or criterion for measuring the dependence of a region on the center. In principle, the greater the contribution of LGR to the APBD, it will show the smaller dependence of the region on the center as a consequence of the implementation of regional autonomy from the principle in a real and responsible manner.

Insukindro et al., (1994) suggested that Local Own Revenue (LGR) can be seen as one indicator or criterion to measure the level of dependence of a region on local government. In principle, the greater the contribution of LGR to the APBD shows the smaller level of regional dependence on regional governments. In the framework of implementing Laws 32 and 35 of 2004, one of the factors that must be prepared by regional governments is regional financial capacity, while the indicator used to measure regional financial capacity is the ratio of PAD compared to the total APBD revenue (Kuncoro. 1995) . 
The principles of regional autonomy adopted (see Law Number 32 of 2004), namely; 1) the implementation of regional autonomy is carried out and pay attention to aspects of democracy, justice, equity, and the potential of regional diversity. 2) The implementation of regional autonomy is based on broad, real and responsible autonomy. 3) The implementation of broad and complete regional autonomy is placed in the regency and city areas, while the provincial autonomy is limited autonomy. 4) The implementation of regional autonomy must be in accordance with the State's constitution, so that there will be harmonious relations between the center and the regions and between regions. 5) The implementation of regional autonomy must further enhance the autonomy of the autonomous region and therefore in the regency and municipal areas there are no more administrative areas. Likewise in special areas that are fostered by the government or other parties, such as authority agencies, port areas, forestry areas, new urban areas, tourism areas or the like, the provisions of autonomous regional regulations apply. 6) The implementation of regional autonomy must further enhance the role and function of the regional legislative body, both as a function of legislation, as a function of supervision as well as a function of the budget and administration of regional governments. With a very fundamental change in the law, the impact felt by the regional government is not only related to a change in the system or structure of the local government, but also concerning the readiness and availability of the apparatus of human resources, both quantitatively and qualitatively, acting as a function and function as the driving force of the region that is strong, effective and efficient, and has accountability.

Economic growth is one of the benchmarks that can be used to increase the development of an area of various economic sectors indirectly reflecting the level of economic change. According to Sukirno (1994), economic growth means the development of activities in the economy which causes the goods and services produced to increase and people's prosperity to increase.

As one of the autonomous regions, North Toraja Regency continues to improve itself to increase sources of revenue to create regional independence. Even though the fiscal conditions in North Toraja Regency from the four components of revenue sources namely regional taxes, regional levies, the results of the management of separated regional assets and other valid PAD have not yet played an optimal role.

The consequence of the implementation of regional autonomy lies in the ability of regional finances to finance the administration of its government, so it is only natural that PAD is used as a benchmark in the implementation of regional autonomy. However, the problem is the proportion of revenue that comes from the Regency PAD is small in number, so that there is an imbalance in the area of finance between capability and needs. This condition has created district government dependence on the central government, so that the autonomy that is expected to create such independence may be difficult to implement.

\section{LITERATURE REVIEW}

\section{$>$ Regional Autonomy}

The term autonomy comes from the Greek language, which is outus which means itself and nomos means law. According to the historical development of government in Indonesia, autonomy in addition to containing the meaning of legislation also contains the meaning of government or its own legislation (Pamudji, 1982).

In accordance with Article 1 point (h) of Law Number 32 of 2004 concerning Regional Government and Law Number 35 of 2004 concerning Financial Balance between Central and Regional Governments, it is stated that regional autonomy is the authority to regulate and manage the interests of local communities according to the initiative itself or the aspirations of the people in accordance with statutory regulations.

The purpose of granting regional autonomy is to enable the region concerned to regulate and manage its own households in order to improve the effectiveness and results of the administration of government for community services and implementation of development. To carry out these objectives, the region is given the authority to carry out government affairs.

According to the University of Gadjah Mada FISIPOL Team (1991), there are four elements of regional autonomy, namely 1) having its own regional apparatus which is marked by the existence of the Regional Head, DPRD, and Regional Employees. 2) have their own household affairs that are marked by the presence of regional offices. 3) Has its own financial source which is marked by the presence of local taxes, regional levies, regional companies and the revenue of regional offices. 4) Has the authority to carry out his own initiative (outside of instructions from the central government or superiors) as long as it does not conflict with the higher laws and regulations.

The principle / essence of regional autonomy is having its own financial resources, managing and using it to carry out autonomy tasks, and having a self-determined budget. In the implementation of regional autonomy, there are three determining factors, namely the tools, personnel, and financing or regional funding.

\section{$>$ Regional Revenue and Expenditures Budget}

According to Permendagri Number 21 of 2011, "Regional Revenue and Expenditure Budget (APBD) is the annual financial plan of the regional government which is discussed and agreed upon jointly by the regional government and DPRD (Regional People's Representative Council), and determined by regional regulations". 
Fiscal policy is usually interpreted as government actions in the field of the National Budget (APBN) at the national level, and the Regional Budgeting and Expenditure Budget (APBD) at the regional level. The budget illustrates the details of government operational and development activities expressed in rupiah for a certain period and is an elaboration of the GBHN and Repelita. Tallo (1997) states that the Regional Revenue and Expenditure Budget, which is often called the regional budget, is that the autonomous regional income and expenditure budget includes routine and development budgets, with each having an income and expenditure side.

The understanding of the system and mechanism adopted by the APBN is the same for the APBD, in the context of development planning it is understood to be essentially an operational form of an annual activity plan. The APBN is a translation of Repelita at the national level and the APBD as a translation of Repelita at the regional level. The budget describes in detail the amount of the cost of a balanced need between revenues and expenditures, called a dynamic balanced budget system. A dynamic balanced budget gives the meaning that the amount of the budgeted budget on the revenue side should be balanced with the amount on the expenditure side where there is a change in the budget if there is a disagreement with the established budget.

\section{Locally-generated revenue (LGR)}

Locally-generated revenue (LGR) is regional income that comes from regional financial sources such as local taxes, regional retiribusi, share of BUMD profit, service receipts and other revenues (Kaho, 1998). LGR can give its own color to the economic level of a region, because this type of income can be used freely by the region. LGR is a source of regional finance that is extracted within the region concerned consists of the results of local taxes, the results of regional levies, the results of regionally owned companies and the results of the management of other separated regional assets, as well as other legitimate Regional Original Revenues.

In order to analyze regional financial capacity, it is necessary to pay attention to the basic provisions regarding regional income and financing sources based on Law Number 32 of 2004 and Law Number 35 of 2004. According to Article 79 of Law Number 32 of 2004 states that the source of income area consists of:

- Locally-generated revenue (LGR)), namely:

$\checkmark$ Local tax and retribution results
Results of regionally owned companies

$\checkmark$ The results of the management of separated regional assets

- Balance funds.

- Regional loans

- Other legal regional income

\section{$>$ Regional Financial Capability}

Another important criterion for knowing the region's real ability to manage and manage its households is the region's ability in the financial sector. In other words, the financial factor is an important factor in regulating the level of regional capability in implementing regional autonomy. In Government Regulation No. 105/2000, states that regional finance is the rights and obligations of the region in the context of administering local governments that can be valued in money including all other assets related to the rights and obligations of the region within the APBD framework.

In connection with the importance of the financial position, regional finance as one indicator to determine the ability of the region in managing and managing their own households. With the issuance of a law on Regional Autonomy, it has consequences for regions that will cause differences between one region and another, especially in terms of regional financial capacity, among others (Nataluddin, 2001).

\section{METHODOLOGY}

In this study, several indicators to assess regional financial capacity include, the ratio of the degree of fiscal decentralization, the ratio of regional financial dependency, the ratio of independence, the effectiveness of LGR, the efficiency ratio of Locally-generated revenue (LGR), the ratio of routine capability index and the ratio of LGR growth. An assessment of the region's financial capacity is an indicator of the implementation of regional autonomy.

The variables used in this study are financial ratios consisting of degrees of fiscal autonomy, regional financial dependency ratios, independence ratios, LGR effectiveness ratios, LGR efficiency ratios, routine capability index ratios and LGR growth ratios. This research was conducted at the Regional Toraja Finance and Asset Management Agency (BPKAD) in North Toraja where the object of study was regional finance from 2014-2019. The time in this study began in August 2019 until the end. 


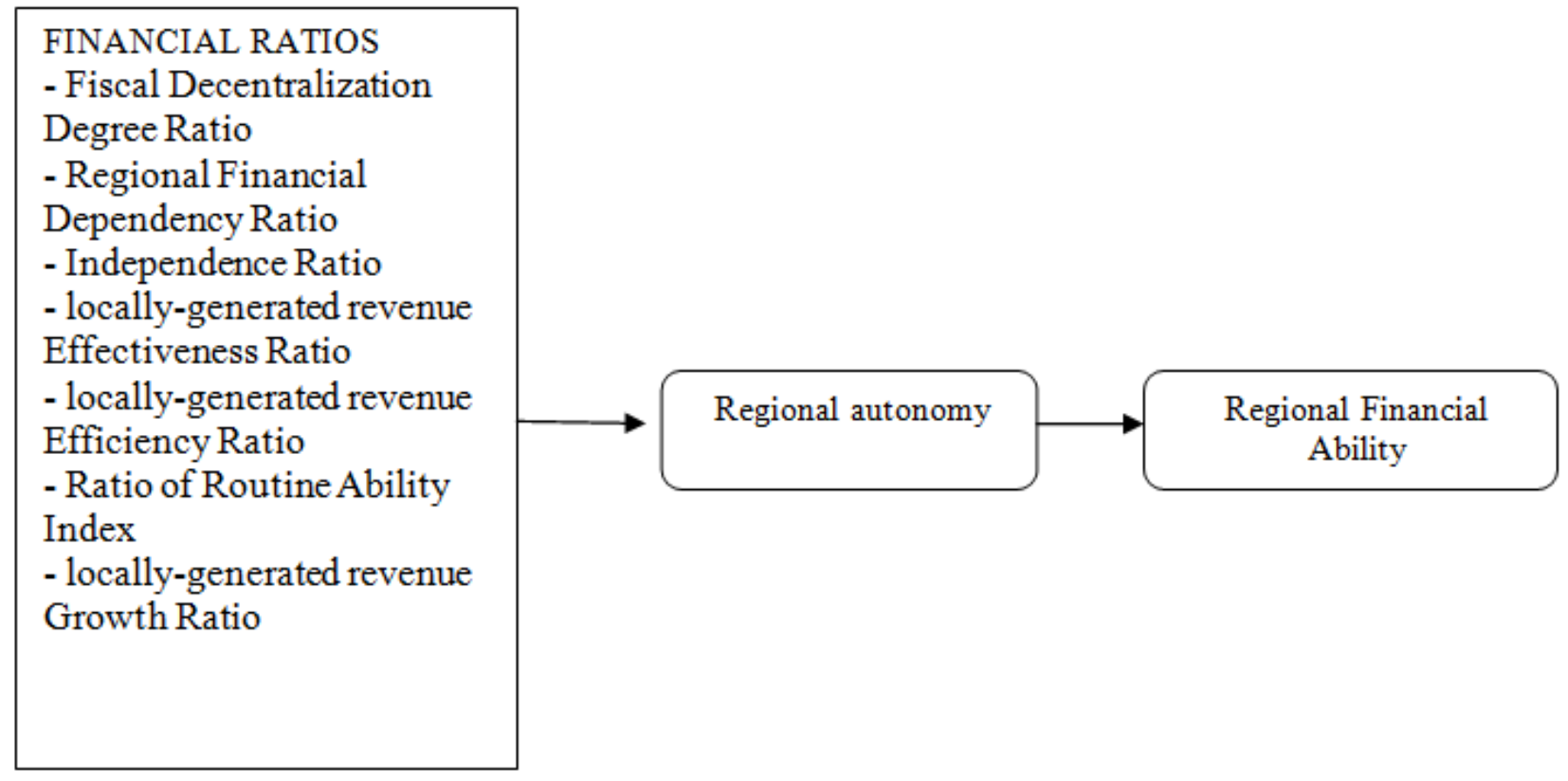

Fig 1:- Conceptual Framework

\section{A. Financial Ratio Analysis}

In this study the data was calculated using financial ratio analysis to determine the financial capabilities in supporting the implementation of regional autonomy in North Toraja Regency. Some financial ratios used in analyzing regional financial capabilities include:

\section{Ratio of Fiscal Decentralization Degrees}

The degree of decentralization is calculated based on a comparison between the total Original Regional Revenue and the Total Regional Revenue. This ratio shows the contribution of locally-generated revenue to total regional revenue. The higher the contribution of locally-generated revenue, the higher the ability of regional finances in carrying out decentralization. (DDF):

To measure the degree of fiscal decentralization

$\mathrm{DDF}=\frac{\text { PADt }}{\mathrm{TPDt}} \times 100 \%$

\section{Regional Financial Dependency Ratio}

The ratio of regional financial dependency is calculated by comparing the amount of transfer revenue received by the region with the total regional revenue. The higher this ratio, the greater the level of dependence of regional governments on central and / or provincial government revenues. This ratio is formulated as follows (Mahmudi, 2010).

\section{Regional Financial Independence Ratio}

This ratio illustrates the level of regional dependence on external assistance. The higher the ratio of independence, it means that the level of regional dependence on external parties (especially the central and provincial governments) is getting lower, and vice versa. (Mahmudi, 2010).

\section{$>$ locally-generated revenue Effectiveness Ratio}

One of the successes of a local government in carrying out the wheels of government, one of which can be measured by the effectiveness of the budget implementation. The measurement of the level of effectiveness is to determine the success or failure to achieve budget goals that require data on the realization of revenue and revenue targets, Bisma, (2010). According to Munir (2004) that the analysis of the effectiveness of local budget management is to use a comparison ratio between the realization of locally-generated revenue and locallygenerated revenue targets set in the APBD, in order to determine the success or failure of the achievement of budget objectives.

\section{locally-generated revenue Efficiency Ratio}

To find out whether a government activity has been carried out efficiently or not, it can be seen from the efficiency ratio. Mardiasmo (2004) said that efficiency is measured by the ratio between the ratio of output to input, the greater the output compared to the input, the higher the level of efficiency of an organization. This ratio is calculated by comparing the costs incurred by local governments to obtain locally-generated revenue with the realization of locally-generated revenue revenue.

\section{Routine Capability Index Ratio}

The routine capability index ratio illustrates the large capacity of local governments to finance routine expenditure in carrying out their government activities. The higher the ratio of routine capability ratios, the higher the financial capacity in supporting regional autonomy. 


\section{> locally-generated revenue Growth Ratio}

Locally-generated revenue growth ratio illustrates how much the ability of local governments in maintaining and increasing success achieved from period to period. If the higher locally-generated revenue, TRR and development spending are followed by lower routine spending, then growth will be positive. This means that the region is able to maintain and increase its growth from period to period.

\section{RESULTS AND DISCUSSION}

In line with the demands for democratization in the state, the administration of government has also changed. The system of government which was initially more inclined to be centralized became decentralized. In line with these changes, the rules also experienced changes that are more directed at improving the implementation of regional autonomy, through giving the widest possible authority while maintaining the integrity of the Unitary State of the Republic of Indonesia. Various improvements were made as stipulated in Law No. 33 of 2004, which is a refinement of Law No. 25 of 1999. The granting of authority is given both in terms of revenue and regional financial expenditure.
Regional income is a source of regional government revenue that will be used to finance regional development. Regional income in North Toraja Regency during the 20142019 period increased. Thus the implementation of fiscal decentralization policy that is the delegation of authority from the central government to regional governments in managing regional income in line with the increasing amount of APBD by the North Toraja district government. The increase in regional income is also expected to be able to increase regional independence in financing development and determining development priorities in accordance with available resources. In addition, local governments are also expected to be able to manage the budget appropriately because in this era of fiscal decentralization, regional income is the main capital in development.

Total regional income consists of several components, namely regional own-source revenue, tax and non-tax revenue sharing, general allocation fund, special allocation fund and other legal income. The development of regional revenue components in North Toraja can be seen in the following table:

\begin{tabular}{|c|c|c|c|c|c|}
\hline Years & 2015 & 2016 & 2017 & 2018 & 2019 \\
\hline locally-generated revenue & 33,7 & 3,2 & 26,6 & $-5,0$ & 23,6 \\
\hline Local tax & 18,1 & 7,2 & 46,8 & 13,5 & 6,4 \\
\hline Regional Retribution & $-15,3$ & 11,8 & 26,5 & 49,8 & 17,9 \\
\hline $\begin{array}{l}\text { Separate Regional Wealth } \\
\text { Management Results }\end{array}$ & 43,3 & 39,8 & 21,9 & $-6,8$ & 13,1 \\
\hline $\begin{array}{l}\text { Other Legal locally-generated } \\
\text { revenue }\end{array}$ & 107,6 & $-10,6$ & 10,3 & $-62,8$ & 108,6 \\
\hline Funds Transfer & 11,5 & 8,8 & 5,0 & 11,9 & $-4,0$ \\
\hline Tax / Non Tax & $-50,0$ & 39,5 & $-23,4$ & 9,3 & $-12,0$ \\
\hline general allocation fund & 5,1 & 11,9 & $-1,8$ & 0,1 & 6,7 \\
\hline special allocation fund & 25,3 & 23,1 & 35,5 & 46,3 & $-24,8$ \\
\hline Other legal regional income & 27,4 & $-3,5$ & 12,8 & 21,4 & 37,0 \\
\hline Total Regional Revenue & 10,8 & 10,3 & 7,3 & 13,0 & 5,6 \\
\hline
\end{tabular}

Table 1:- Revenue Growth in North Toraja Regency in 2015-2019

Source: Regional Financial and Asset Management Agency, processed.

Based on Table 1, the growth in Total Regional Revenue (TRR) tends to fluctuate, with an average growth of 9.4 percent. In 2015 TRR growth of 10.8 percent then decreased in 2016 which only grew by 10.3 percent due to decreased growth in locally-generated revenue and fund transfers and negative growth occurred on the other side of legal income. In 2017 the decline again only grew by 7.3 percent due to a significant decrease in the growth of transfer funds even though the growth of locally-generated revenue had increased. This is because transfer funds have a large contribution to TRR. In 2018 TRR growth again increased by 13 percent due to an increase in the growth of transfer funds even though revenue from locally-generated revenue experienced negative growth, then in 2019 TPD growth declined again which only grew by 5.6 percent due to negative transfer fund growth.
Growth in the regional revenue component from the locally-generated revenue side in 2015-2019 tends to fluctuate. In 2015 it grew by 33.7 percent then experienced a significant decrease in 2016 which only grew by 3.2 percent due to other miscellaneous revenue which grew negatively and decreased regional tax growth and the results of the management of separated regional wealth. In 2017, growth again increased by 26.6 percent and then grew negatively by 5.0 percent in 2018 due to declining growth in regional taxes as well as the lack of growth in the results of the management of separated regional assets and other legitimate locally-generated revenue. In 2019 it will again grow significantly by 23.6 percent.

Growth in transfer funds annually also tends to fluctuate. In 2015 it grew by 11.5 percent then decreased in 2016 which only grew by 8.8 percent due to the decline in 
special allocation fund growth. In 2017 there was a decline that only grew by 5 percent because tax and non-tax revenue sharing and general allocation fund grew negatively. In 2018, it will grow again significantly by 11.9 percent and in 2019 the growth will be negative by 4.0 percent due to tax and non-tax revenue sharing and special allocation fund growing negatively.

\section{Contribution of Local Original Revenue Sources}

Locally-generated revenue (LGR) is regional income sourced from the results of Regional Taxes, Regional Levies, Management Results of Separated Regional Wealth, and Other Authorized Regional Original Revenues.
Regional Original Income is considered as an alternative source of regional funding that is used by the region as an expenditure to carry out governance and development in order to minimize the dependence of the region on subsidies from the central government. The intended contribution is the amount of contribution that can be made by the sources and their components to the total own-source revenue and to the Regional Income which is seen as a percentage every fiscal year. The amount of contribution can also reflect the magnitude of the role of each of these LGR sources. For a clearer picture of the contribution of LGR sources can be seen in the following figure.
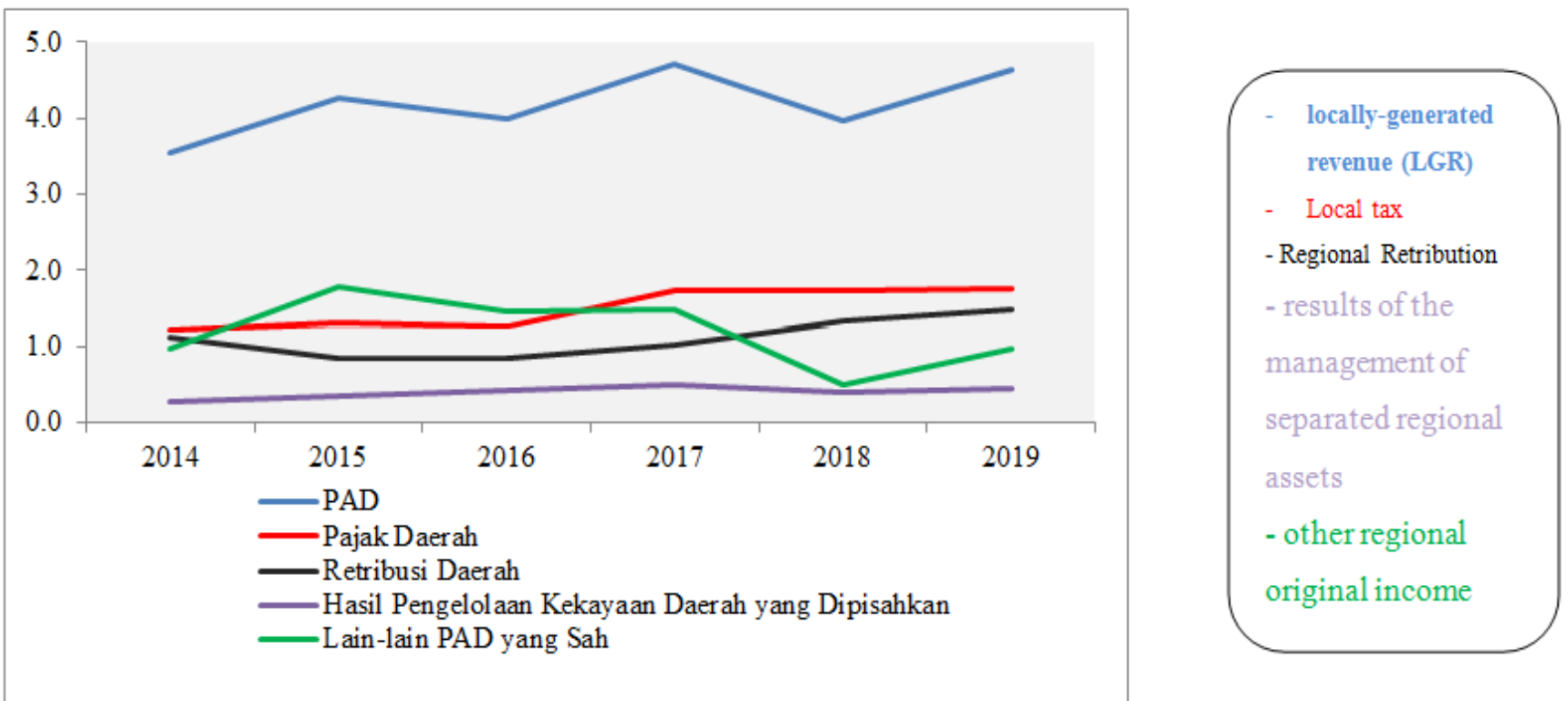

Fig 2:- Contribution of PAD to TPD of North Toraja Regency in 2014-2019

Source: Regional Financial and Asset Management Agency, processed

It can be seen in Figure 2 that the contribution of LRG to TPD in North Toraja Regency tends to fluctuate annually by an average contribution of 4.2 percent. In 2014-2015 the contribution of LRG to TRR has increased from 3.5 percent to 4.3 percent then in 2016 there was a decrease which only contributed 4 percent due to the decrease in other contributions to legitimate LRG. In 2017, it increased again by 4.7 percent and decreased in 2018 by only 4 percent due to the decreasing contribution of the results of the management of separated regional wealth and other legal LRG. In 2019 it will again increase by 4.6 percent.

Based on Figure 2 above, the contribution of local taxes to TRR of North Toraja Regency in 2014-2019 continues to increase each year, with an average contribution of 1.5 percent, while the contribution of regional fees each year tends to fluctuate in 2014-2015 continuing to decrease each by 1,1 percent and 0.8 percent, 2016-2019 continued to increase respectively by 0.9 percent, 1 percent and 1.3 percent with an average contribution of 1.1 percent. The contribution of regional wealth management results separated each year also tends to fluctuate, in 2014-2017 there was an increase and in 2018-2019 there was a decrease with an average contribution of 0.4 percent. Other contributions Legitimate locally-generated revenue tends to fluctuate with an average contribution of 1.2 percent. If seen from the average contribution of the largest locally-generated revenue component comes from the local tax which is 1.5 percent then the other valid locally-generated revenue is 1.2 percent.

\section{$>$ Regional Financial Capabilities of North Toraja Regency}

The degree of fiscal decentralization illustrates the level of authority and responsibility given by the central government to local governments to carry out development. LGR is a very determining aspect of the success of a region in carrying out decentralization. The higher the LGR, the greater the ability of local governments to finance regional development. The ratio of the degree of fiscal decentralization in North Toraja Regency was obtained from a comparison between Locally-generated revenue (LGR) and total regional income. 
ISSN No:-2456-2165

\begin{tabular}{|c|c|c|c|c|}
\hline Years & $\begin{array}{c}\text { Realization of } \\
\text { Locally-generated } \\
\text { revenue (Rp. Billion) }\end{array}$ & $\begin{array}{c}\text { Total Regional } \\
\text { Revenue (Rp } \\
\text { billion) }\end{array}$ & $\begin{array}{c}\text { Fiscal Decentralization Degree } \\
\text { Ratio (\%) }\end{array}$ & Level of Fiscal Decentralization \\
\hline 2014 & 25,3 & 714,6 & 3,5 & Very less \\
\hline 2015 & 33,8 & 792,1 & 4,3 & Very less \\
\hline 2016 & 34,9 & 873,3 & 4,0 & Very less \\
\hline 2017 & 44,2 & 937,1 & 4,7 & Very less \\
\hline 2018 & 42,0 & $1.058,8$ & 4,0 & Very less \\
\hline 2019 & 51,9 & $1.118,1$ & 4,6 & Very less \\
\hline
\end{tabular}

Table 2:- Ratio Degrees of Fiscal Decentralization in North Toraja Regency

Source: processed by the author, 2020

Based on Table 2, it is seen that the ratio of Locallygenerated revenue (LGR) to total regional income of North Toraja Regency from 2014-2019 continues to increase although it is relatively small. The lowest degree of fiscal decentralization ratio occurred in 2014 with 3.5 percent. While the highest degree of decentralization ratio in 2017 reached 4.7 percent. The average ratio of the degree of fiscal decentralization in North Toraja Regency during 2014-2019 reached 4.2 percent. It can be concluded that the ratio of the degree of fiscal decentralization in North Toraja Regency over the past 6 years is still in the scale of very poor intervals, because it is still in an interval scale between 0.00-10.00 percent, meaning that the ability of LGR in financing regional development is still lacking.

This shows that the readiness of the regional government of North Toraja Regency in implementing regional autonomy is still lacking. This is in line with the findings of Fattah and Irman (2012) for the South Sulawesi case. The ratio of the degree of fiscal decentralization in South Sulawesi only reached 6.78-8.62 percent, which shows that the financial capacity of local governments in South Sulawesi is still lacking. Such is the case with the findings of Prihatingsih (2011) in Surakarta City which showed that from 2003-2008 the average degree of fiscal decentralization was only 15.56 percent. Thus it can be said that the financial capacity of Surakarta City is not yet independent.

The low degree of regional fiscal decentralization in North Toraja Regency is driven by low regional revenues. The results of interviews with officials within the Regional Financial and Asset Management Agency revealed that the low regional revenue was caused by the high degree of centralization in the taxation field. All the most productive major taxes, both direct and indirect taxes, are withdrawn by the central government. Local taxes are actually quite varied but only a few can be relied upon as a source of revenue, for example hotel taxes, restaurant and restaurant taxes. Regional governments are limited in their space to create revenue sources or expand the revenue base only as stated in Law No. 28/2009 concerning Regional Taxes and Regional Retribution. This limits the local government budget to finance all of its expenditure.

In addition, the low acceptance of the North Toraja Regency is also due to the lack of the role of regional companies as a source of regional income. The lack of role of regional companies as a source of regional revenue is inadequate performance and competitiveness of competitors. In 2018, the number of regional companies will continue to increase to 3,947 . However, this increase was not followed by an increase in regional revenue. Local governments need to conduct policies that are conducive to the development of companies into professional companies, and operationally monitor and evaluate the performance of key companies that are able to encourage competitiveness.

\section{North Toraja Regency Locally-generated revenue (LGR) Growth Ratio}

The Locally-generated revenue (LGR) growth ratio shows the large capacity of local governments in maintaining and increasing success achieved from period to period. North Toraja Regency's Locally-generated revenue (LGR) growth ratio has fluctuated from 2014-2019. In 2014 the ratio of PAD growth reached 4.2 percent. This growth was driven by growth in local taxes, especially street lighting taxes. In 2015, the Locally-generated revenue (LGR) growth ratio increased by 29.5 percent to 33.7 percent. This increase was mainly due to an increase in central government transfer funds. In addition there was indeed an increase in regional tax revenue in terms of hotel taxes and restaurant taxes. In 2016, North Toraja Regency's Locally-generated revenue (LGR) growth ratio experienced a high contraction which reached 3.2 percent. The decline in the Locally-generated revenue (LGR) growth ratio is in line with the decline in regional taxes and transfers. Nominally, the value of Locally-generated revenue (LGR) revenue continues to increase, but in terms of growth is relatively volatile. In 2019, North Toraja Regency's LGR growth ratio will increase to 23.6 percent. This was mainly driven by increased growth in street lighting taxes and transfer funds.

Fluctuation in the ratio of LGR growth in North Toraja Regency shows that the effectiveness of LGR revenue is still very low. This is also in line with the financial independence ratio, which is still very low, so the ups and downs of the North Toraja Regency's LGR growth ratio are largely determined by central or provincial government transfer funds. Based on this LGR growth ratio, it can be said that the financial performance of North Toraja Regency has not been able to implement regional autonomy. 


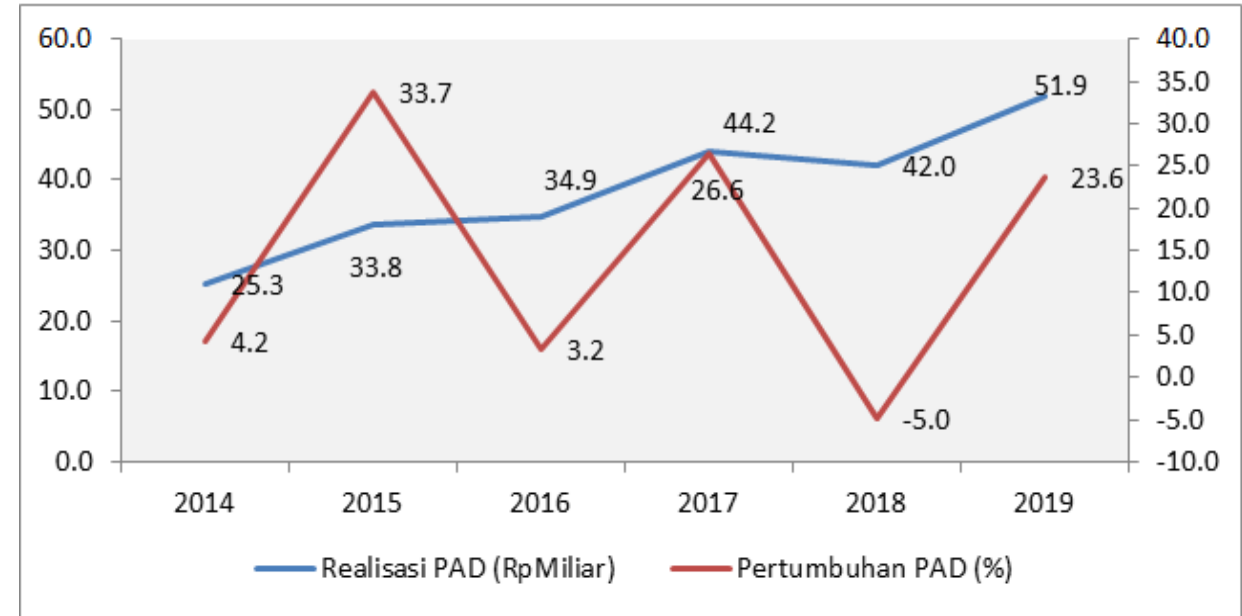

-Realization of LGR (Rp. Billion) -Growth LGR (\%)

Fig 3:- Growth Ratio for North Toraja Regency Locally-generated revenue (LGR) Source: processed by the author, 2020

\section{$>$ Regional Shopping}

Regional Expenditures are all expenditures from the Regional General Cash Account which reduce the equity of current funds, which are regional obligations within one fiscal year. Regional expenditure is used in order to fund the implementation of government affairs which are the authority of the province or district / city. Regional expenditure consists of; employee expenditure, goods and services expenditure, capital expenditure and other expenditure. North Toraja Regency regional expenditure continues to increase every year, to see an overview of the contribution of each Regional Expenditure to North Toraja Regency regional expenditure in 2014-2019 as follows;
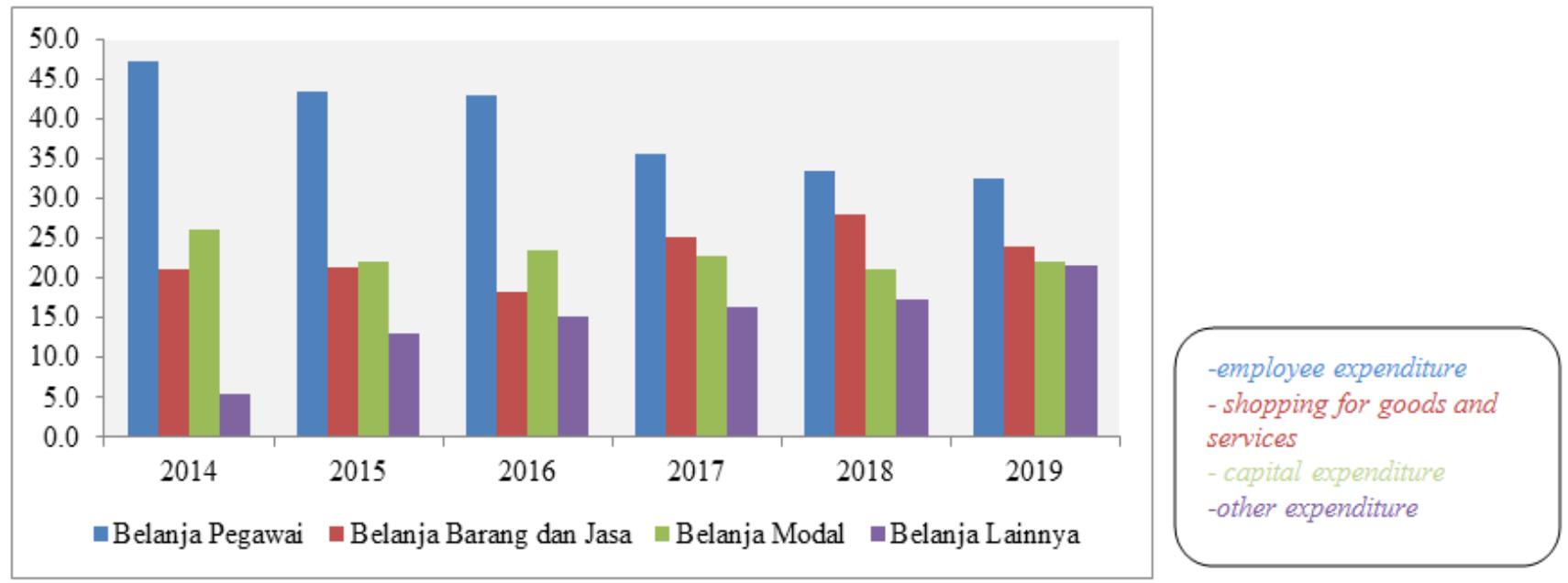

Fig 4:- Development of the Contribution of Each Spending in North Toraja Regency in 2014-2019 Source: Regional Financial and Asset Management Agency, processed

From Figure 4 it can be seen that employee spending in 2014-2019 continues to decline each year with an average contribution of 39.3 percent due to a decline in direct employee spending every year. Expenditures on goods and services in 2014-2019 have tended to fluctuate, with an average contribution of 23 percent. Its contribution to capital expenditure in 2014-2019 has a tendency to fluctuate with an average contribution of 22.9 percent. Other expenditure in 2014-2019 tends to increase every year, with an average contribution of 14.8 percent. If seen from the average percentage of the largest contribution contribution comes from employee expenditure by 39.3 percent then goods and services expenditure by 23 percent.

\section{CONCLUSION}

Based on the analysis and discussion in the previous chapter, it is concluded as follows:

$>$ Total regional income growth in North Toraja Regency in 2014-2019 tends to fluctuate, with an average growth of 9.4 percent.

$>$ Total regional income of North Toraja Regency in 2014-2019 is still dominated by central and provincial government transfer funds with an average of 75.6 percent. While the contribution of Locally-generated revenue (LGR) and other legitimate revenues was 4.2 percent and 20.9 percent, respectively. 
Regional expenditure in North Toraja Regency in 20142019 is still dominated by personnel expenditure with an average of 39.3 percent. While goods and services, capital expenditure and other expenditures were respectively 23 percent, 22.9 percent and 14.8 percent.

Financial capability does not yet support the implementation of regional autonomy in North Toraja Regency in 2014-2019. This is caused by, among others: (1) The ratio of the degree of fiscal decentralization is very less; (2) the financial dependency ratio is very high; (3) The financial independence ratio is very low and has an instructive relationship pattern; (4) The effectiveness ratio of Locally-generated revenue (LGR) is less effective; (5) Locally-generated revenue (LGR) efficiency ratio is less efficient; (6) the ratio of routine ability indexes is very less; (7) Locally-generated revenue (LGR) growth ratio is very volatile.

\section{REFFERENCES}

[1]. Arifin, Zainal, "Kemampuan dan Kesiapan Daerah Kabupaten/Kota dalam Pelaksanaan Otonomi Daerah yang Luas, Nyata dan Bertanggung jawab”, Prisma, Vol XII, No, 3,

[2]. Arikunto, S, (2006), Suhardjono, dan Supardi, 2006, Penelitian tindakan kelas,

[3]. Binder, Brian, B,J, (1984), Ekonomi Keuangan Indonesia, Vol,XXXII, Nomor

[4]. Bisma, I Dewa Gde \& Susanto, Hery, (2010), Evaluasi Kinerja Keuangan Daerah Pemerintahan Provinsi Nusa Tenggara Barat Tahun Anggaran 2003 - 2007, Jurnal Ganec Swara Edisi Khusus Vol, 4 No, 3 ,

[5]. Prayitno, B, (2017), Mengukur Kemampuan Keuangan Daerah Pemerintah Kota Semarang dalam Pelaksanaan Otonomi Daerah Tahun 2013-2017, Jurnal Borneo Administrator/Volume 13/No, 3/2017,

[6]. Dwi Eko Waluyo, (2004), Teori Ekonomi Makro, UMM Press, Malang,

[7]. Dumairy, (1999), Perekonomian Indonesia, Erlangga, Jakarta,

[8]. Halim, A, (2004), Akuntansi keuangan daerah, Jakarta: Salemba Empat,

[9]. Halim, A, (2007), Akuntansi Sektor Publik Akuntansi Keuangan Daerah Edisi Revisi, Jakarta: Salemba Empat,

[10]. Insukindro, M, Widayat, W,, Jaya, W, K,, Purwanto, A, H, Suprihanto, J, \& Purnomo, B, (1994), Peranan Pengelolaan Keuangan Daerah dalam usaha peningkatan PAD, Laporan hasil penelitian KKD,

[11]. Kaho, Josep, (1998), Prospek Otonomi Daerah Melalui Pemberdayaan Ekonomi Masyarakat Lokal, Jurnal Ekonomi Pembangunan, UII, Yokyakarta,

[12]. Kuncoro, M, (1995), Desentralisasi Fiskal di Indonesia: Dilema Otonomi dan Ketergantungan, Prisma, 4, 3-19,
[13]. Kuncoro, Mudrajad, (2000), Ekonomi Pembangunan; Teori, Masalah, dan Kebijakan, Unit Penerbit dan Percetakan Akademi Manajemen Perusahaan YKPN, Yogyakarta,

[14]. Mahmudi, (2010), Manajemen Keuangan Daerah, Jakarta: Erlangga

[15]. Mardiasmo, (2002), Otonomi dan Manajemen Keuangan Daerah, Yokyakarta: Penerbit Andi,

[16]. Memesah, DJ, (1995), Sistem Administrasi Keuangan Daerah, Gramedia Pustaka Utama, Jakarta,

[17]. Miriam Budiardjo (ed,), (1975), Masalah Kenegaraan, Gramedia, Jakarta,

[18]. Munir, D,, \& Djuanda, H, A, (2004), Kebijakan dan Manajemen Keuangan Daerah, Yayasan Pembaruan Administrasi Publik Indonesia,

[19]. Pamudji, S, (1982), Catatan Kuliah Interior Design II,

[20]. Peraturan Menteri Dalam Negeri Nomor 21 Tahun 2011 tentang Pedoman Pengelolaan Keuangan Daerah

[21]. Prihatingsih, A, (2011), Analisis Kemampuan Keuangan Daerah dalam Pelaksanaan Otonomi Daerah di Kota Surakarta Tahun 2003-2008, Tesis

[22]. Ririn, D, Mardiasmo, (2004), The Effect Of Relationship Between Budgetary Participation And Decentralization Structure On Managerial Performance Of Local Government Agencies: The Role Of Organizational Commitment As Intervening Variable,(Empirical Study On Municipality And Regencies in Yogyakarta Province), SOSIOSAINS, 17(4), 655-674,

[23]. Riyadi, dan Bratakusumah, Supriady, Deddy, (2005), Strategi Menggali Potensi Dalam Mewujudkan Otonomi Daerah, Dalam Perencanaan Pembangunan Daerah, PT Gramedia Pustaka Utama, Jakarta

[24]. Sarundajang, (2005), Babak Baru Sistem Pemerintahan Daerah, Kata Hasta Pustaka, Jakarta,

[25]. Savitry, E, Saleh, H, A,, \& Arifin, I, (2011), Analisis Kemampuan Keuangan Daerah dalam Pelaksanaan Otonomi Daerah Tahun 2007-2011 di Kota Makassar, Jurnal Administrasi dan Kebijakan Kesehatan Indonesia, 4(1), 23-34,

[26]. Setijaningsih, (2011), Analisis Kemampuan Keuangan Daerah Kabupaten Madiun Tahun 2003-2010, Tesis

[27]. Smith, B,C, (1985), Decentralization, George Alle \& Unwin, London,

[28]. Suparmoko M, (1992), Keuangan Negara dalam Teori dan Praktek, Penerbit BP-FE, Yogyakarta,

[29]. Sukirno, S, (1994), Pengantar Ekonomi Makro, Edisi Kedua, Jakarta: PT, Rajagrafindo Perkasa,

[30]. Syaukani, Gaffar A, dan Rasyid, M, Ryaas, (2002), Otonomi Daerah Dalam Negara Kesatuan, Pustaka Pelajar dan Pusat Pengkajian Etika Politik dan Pemerintahan, Yogyakarta

[31]. Tangkilisan, H, N, S, (2005), Manajemen publik, Grasindo

[32]. Thee Kian Wie (1983), Pembangunan Ekonomi dan Pemerataan, Pendekatan Alternatif, Ghalia, Jakarta,

[33]. Todaro, Michael P, (2000), Economic Development, Seventh Edition, Addison-Wesley, England, 
[34]. Utomo, L, L, (2000), Instrumen Derivatif: Pengenalan dalam Strategi Manajemen Risiko Perusahaan, Jurnal akuntansi dan keuangan, 2(1), 53-68,

[35]. Universitas Gadjah Mada, Fakultas Ilmu Sosial, \& Ilmu Politik, (1991), Alternatif kebijaksanaan pengembangan kelembagaan Badan Perencanaan Pembangunan Daerah (Bappeda) Tingkat II di Propinsi Jawa Tengah dan Propinsi Daerah Istimewa Yogyakarta, Fakultas Ilmu Sosial dan Ilmu Politik, Universitas Gadjah Mada,

[36]. Undang-Undang Nomor 32 Tahun 2004 tentang Pemerintahan Daerah,

[37]. Undang-Undang Nomor 33 Tahun 2004 tentang Perimbangan Keuangan Antara Pemerintah Pusat dan Pemerintah Daerah 